\title{
PENARIKAN ARTIKEL \\ ANALISIS PERLAKUAN AKUNTANSI TANAMAN PRODUKTIF BERDASARKAN PSAK 16 PADA CV BUDI BAKTI AGRO
}

\author{
Hamdani Arifulsyah ${ }^{1}$, Fany Meilani ${ }^{2}$, Suci Nurulita ${ }^{3}$ \\ ${ }^{1,2,3}$ Politeknik Caltex Riau, Pekanbaru \\ Email: dani@pcr.ac.id \\ Penarikan Artikel
}

Berdasarkan hasil reviu yang cermat, hati-hati, dan penuh pertimbangan dari artikel yang berjudul ANALISIS PERLAKUAN AKUNTANSI TANAMAN PRODUKTIF BERDASARKAN PSAK 16 PADA CV BUDI BAKTI AGRO Vol 6 (1), 119-128, 2020, makalah ini dinyatakan melanggar prinsip publikasi JIAFE (Jurnal Ilmiah Akuntansi Fakultas Ekonomi) dan telah ditarik kembali.

Editor menyelidiki dan menemukan bahwa makalah yang diterbitkan di JABI (Jurnal Akuntansi Berkelanjutan Indonesia), Vol. 3 (2), hIm. 193-203, 2020.

Dokumen dan isinya telah dihapus dari JIAFE (Jurnal IImiah Akuntansi Fakultas Ekonomi) dan upaya yang wajar harus dilakukan untuk menghapus semua referensi ke artikel ini.

\section{KETERANGAN ARTIKEL}

Arifulsyah, H. dkk. (2020). Analisis Perlakuan Akuntansi Tanaman Produktif Berdasarkan Psak 16 pada CV Budi Bakti Agro. JIAFE (Jurnal Ilmiah Akuntansi Fakultas Ekonomi), 6(1), 119-128. https://doi.org/10.34204/jiafe.v6i1.2015

Copyright $@ 2020$. JIAFE (Jurnal Akuntansi Ilmiah Fakultas Ekonomi) Universitas Pakuan 